\title{
EDITORIAL Twenty years of IJIR
}

International Journal of Impotence Research (2008) 20, 429-430; doi:10.1038/ijir.2008.37

Twenty years ago, the International Journal of Impotence Research (IJIR) launched as the first journal for sexual dysfunction. As IJIR's fifth Editor-in-Chief, it has been extremely rewarding to see the field of sexual medicine grow over this time as well. As the field has grown, so has the journalsince the journal's inception, IJIR's scope has developed and changed to include female sexual dysfunction, cardiology, endocrinology, neurology and psychology.

A very basic goal of the journal from the very beginning was to publish both basic science and clinical studies. To this end, we have fulfilled that goal and published several noteworthy important papers along the way. We published the classic epidemiologic study by Braun et al. ${ }^{1}$ evaluating nearly 5000 men in Germany (the Cologne Male Survey). The data revealed striking results. The authors concluded that regular sexual activity is a normal finding in advanced age. Erectile dysfunction (ED) is a frequent disorder, contributing to dissatisfaction with sexual life in a considerable proportion of men and adequate diagnostic workup is essential to offer patients individually adapted treatment. These data shed light on a variety of sexual issues heretofore underappreciated and underreported.

The paper by Park et $a .^{2}{ }^{2}$ investigated the physiology and pathophysiology of female sexual dysfunction. The authors developed an animal model of vaginal engorgement insufficiency and clitoral erectile insufficiency and found that vaginal engorgement and clitoral erection depended on the increased blood inflow. In addition, atherosclerosis was associated with vaginal engorgement insufficiency and clitoral erectile insufficiency.

Eleven years ago, the journal published one of the first studies to show a correlation between cardiac function and ED by Greenstein et al. ${ }^{3}$ The authors noted a statistically significant correlation between erectile function and the number of coronary vessels involved. Patients with one-vessel disease had more $(P<0.04)$ and firmer erections $(P<0.001)$ with fewer difficulties in achieving an erection $(P<0.007)$ than men with two- or three-vessel disease.

IJIR also published the first IC351 (tadalafil) paper, ${ }^{4}$ and more recently a pivotal study of daily tadalafil dosing. ${ }^{5}$ Several of the earliest sildenafil ${ }^{6,7}$ and vardenafil papers ${ }^{8}$ also have published in the Journal. And, the journal published the first information on the validated psychometric instrument, Structured Interview on Erectile Dysfunction, ${ }^{9}$ along with the IIEF- $5^{10}$ and the validation of the Self-esteem and Relationship questionnaire. ${ }^{11}$ IJIR has published the seminal work on PT-141 and phentolamine ${ }^{12-14}$ and was at the forefront of publishing data on penile injection therapy ${ }^{15}$ and on penile rehabilitation after a radical prostatectomy. ${ }^{16,17}$

Recently, IJIR published an important paper by Sesti et al. ${ }^{18}$ continuing the interest of the cardiovascular link to ED. The aim of the study was to determine, in an animal model, the effects of tadalafil on myocardial infarct size, hemodynamics and regional myocardial blood flow after myocardial ischemia and reperfusion. Another recent groundbreaking paper of significance is by Song et al. ${ }^{19}$ on the first human bone marrow-derived mesenchymal stem cells for possible cell therapy in patients suffering from ED. Wayman et al. ${ }^{20}$ also published important data on PDE11 knockout mice and sperm physiology.

Other recent articles include Eaton et al. ${ }^{21}$ who provide significant epidemiologic data using a subcohort of almost 1000 men between the ages of 46-81 years. The authors concluded that the selected biomarkers for endothelial function, thrombosis and dyslipidemia, but not inflammation, are associated with the degree of ED in this crosssectional analysis. And, Svartberg et al. ${ }^{22}$ provide important data on testosterone replacement in older men and concluded that testosterone treatment improved the body composition, but it did not reverse an unfavorable metabolic profile.

Following in the same tradition of excellence and in celebration of IJIR's 20th anniversary, we have created this special commemorative issue that presents five review articles from the notables in the field. We are honored and privileged to have my dear friend, Jacob Rajfer ${ }^{23}$ who provides an indepth report of his discovery of NO, which is undoubtedly the most important scientific discovery in the field of male sexual medicine in the past 20 years. Dr Karl Montague, a pioneer in the field of penile prosthetics, and his colleague ${ }^{24}$ provide a nice presentation of the past, present and future of penile prosthesis implantation. Tom Lue, an esteemed colleague and mentor, who has been involved in sexual medicine for over two decades, and his colleagues ${ }^{25}$ have written a contemporary overview of Peyronie's disease. Robert Kloner ${ }^{26}$, an outstanding research 
scientist, provides an authoritative review of the potential for ED to predict coronary disease. Finally, Rosemary Basson, ${ }^{27}$ a luminary in female sexual dysfunction, presents an overview of the current uncertainties and future directions field's.

I remain absolutely confident that the next 20 years will continue to bring about important advances that not only elucidate fundamental mechanisms but also serve as the basis for the improved diagnosis and treatment. The most critical future developments in this field will be published in the pages of IJIR. And for that, I thank my distinguished and eminent editorial board/ reviewers and the outstanding researchers who submit their papers to the journal-my reward is the opportunity to review and publish these contributions.

Happy 20th, IJIR.

\section{AD Seftel \\ Editor-in-Chief, IJIR \\ Department of Urology, Case Western Reserve University, Cleveland, OH, USA}

\section{References}

1 Braun M, Wassmer G, Klotz T, Reifenrath B, Mathers M, Engelmann U. Epidemiology of erectile dysfunction: results of the 'Cologne Male Survey'. Int J Impot Res 2001; 12: 305-311.

2 Park K, Goldstein I, Andry C, Siroky MB, Krane RJ, Azadzoi KM. Vasculogenic female sexual dysfunction: the hemodynamic basis for vaginal engorgement insufficiency and clitoral erectile insufficiency. Int J Impot Res 1997; 9: 27-37.

3 Greenstein A, Chen J, Miller H, Matzkin H, Villa Y, Braf Z. Does severity of ischemic coronary disease correlate with erectile function? Int J Impot Res 1997; 9: 123-126.

4 Padma-Nathan H, McMurray JG, Pullman WE, Whitaker JS, Saoud JB, Ferguson KM et al. On-demand IC351 (Cialias) enhances erectile function in patients with erectile dysfunction. Int J Impot Res 2001; 13: 2-9.

5 Rajfer J, Aliotta PJ, Steidle CP, Fitch WP, Zhao Y, Yu A. Tadalafil dosed once a day in men with erectile dysfunction: a randomized, double-blind, placebo-controlled study in the US. Int J Impot Res 2007; 19: 95-103.

6 Boolell M, , Allen MJ, Ballard SA, Gepi-Attee S, Muirhead GJ, Naylor AM et al. Sildenafil: an orally active type 5 cyclic GMP-specific phosphodiesterase inhibitor for the treatment of penile erectile dysfunction. Int J Impot Res 1996; 8: 47-52.

7 Morales A, Gingell C, Collins M, Wicker PA, Osterloh IH. Clinical safety of oral sildenafil citrate (VIAGRATM) in the treatment of erectile dysfunction. Int J Impot Res 1998; 10: 69-74.

8 Bischoff E, Schneider K. A conscious-rabbit model to study vardenafil hydrochloride and other agents that influence penile erection. Int J Impot Res 2001; 13: 230-235.

9 Petrone L, Mannucci E, Corona G, Bartolini M, Forti G, Giommi R et al. Structured interview on erectile dysfunction (SIEDY): a new, multidimensional instrument for quantification of pathogenetic issues on erectile dysfunction. Int J Impot Res 2003; 15: 210-220.

10 Rosen RC, Cappelleri JC, Smith MD, Lipsky J, Peña BM. Development and evaluation of an abridged, 5 -item version of the International Index of Erectile Function (IIEF-5) as a diagnostic tool for erectile dysfunction. Int J Impot Res 1999; 11: 319-326.

11 Cappelleri JC, Althof SE, Siegel RL, Shpilsky A, Bell SS, Duttagupta S. Development and validation of the self-esteem and relationship (SEAR) questionnaire in erectile dysfunction. Int J Impot Res 2004; 16: 30-38.

12 Rosen RC, Diamond LE, Earle DC, Shadiack AM, Molinoff PB. Evaluation of the safety, pharmacokinetics and pharmacodynamic effects of subcutaneously administered PT-141, a melanocortin receptor agonist, in healthy male subjects and in patients with an inadequate response to Viagra. Int J Impot Res 2004; 16: 135-142.

13 Diamond LE, Earle DC, Rosen RC, Willett MS, Molinoff PB. Double-blind, placebo-controlled evaluation of the safety, pharmacokinetic properties and pharmacodynamic effects of intranasal PT-141, a melanocortin receptor agonist, in healthy males and patients with mild-to-moderate erectile dysfunction. Int J Impot Res 2004; 16: 51-59.

14 Padma-Nathan H, Goldstein I, Klimberg I, Coogan C, Auerbach S, Lammers P. Long-term safety and efficacy of oral phentolamine mesylate (Vasomax) in men with mild to moderate erectile dysfunction. Int J Impot Res 2002; 14: 266-270.

15 Heaton JPW, Lording D, Liu SN, Litonjua AD, Guangwei L, Kim SC et al. Intracavernosal alprostadil is effective for the treatment of erectile dysfunction in diabetic men. Int J Impot Res 2001; 13: 317-321.

16 Nandipati K, Raina R, Agarwal A, Zippe CD. Early combination therapy: intracavernosal injections and sildenafil following radical prostatectomy increases sexual activity and the return of natural erections. Int J Impot Res 2006; 18: 446-451.

17 Padma-Nathan H, McCullough AR, Levine LA, Lipshultz LI, Siegel R, Montorsi F et al. Randomized, double-blind, placebo-controlled study of postoperative nightly sildenafil citrate for the prevention of erectile dysfunction after bilateral nerve-sparing radical prostatectomy. Int J Impot Res 2008; 20: 479-486 (this issue).

18 Sesti C, Florio V, Johnson EG, Kloner RA. The phosphodiesterase-5 inhibitor tadalafil reduces myocardial infarct size. Int J Impot Res 2007; 19: 55-61.

19 Song YS, Lee HJ, Park IH, Kim WK, Ku JH, Kim SU. Potential differentiation of human mesenchymal stem cell transplanted in rat corpus cavernosum toward endothelial or smooth muscle cells. Int J Impot Res 2007; 19: 378-385.

20 Wayman C, Phillips S, Lunny C, Webb T, Fawcett L, Baxendale $\mathrm{R}$ et al. Phosphodiesterase 11 (PDE11) regulation of spermatozoa physiology. Int $J$ Impot Res 2005; 17: 216-223.

21 Eaton CB, Liu YL, Mittleman MA, Miner M, Glasser DB, Rimm EB. A retrospective study of the relationship between biomarkers of atherosclerosis and erectile dysfunction in 988 men. Int J Impot Res 2007; 19: 218-225.

22 Svartberg J, Agledahl I, Figenschau Y, Sildnes T, Waterloo K, Jorde R. Testosterone treatment in elderly men with subnormal testosterone levels improves body composition and BMD in the hip. Int J Impot Res 2008; 20: 378-387.

23 Rajfer J. Discovery of NO in the penis. Int J Impot Res 2008; 20 : 431-436 (this issue).

24 Simmons M, Montague DK. Penile prosthesis implantation: past, present and future. Int J Impot Res 2008; 20: 437-444 (this issue).

25 Smith JF, Walsh TJ, Lue TF. Peyronie's disease: a critical appraisal of current diagnosis and treatment. Int J Impot Res 2008; 20: 445-459 (this issue).

26 Kloner RA. Erectile dysfunction as a predictor of cardiovascular disease. Int J Impot Res 2008; 20: 460-465 (this issue).

27 Basson R. Women's sexual function and dysfunction: current uncertainties, future directions. Int J Impot Res 2008; 20: 466-478 (this issue). 